\title{
Behavior and blood profile in Friesian-Holstein dairy cows in the special region of Yogyakarta, Indonesia
}

\author{
Mohammad Firdaus Hudaya (D. Pradita Iustitia Sitaresmi (D. Cuk Tri Noviandi (iD. Budi Prasetyo Widyobroto iD. \\ Diah Tri Widayati
}

\section{MF Hudaya - PI Sitaresmi - DT Widayati (Corresponding author) \\ Department of Animal Genetics and Reproduction, Faculty of Animal Science, Universitas Gadjah Mada, Yogyakarta, Indonesia.}

email: widayati@ugm.ac.id

\section{CT Noviandi}

Department of Animal Nutrition, Faculty of Animal Science, Universitas Gadjah Mada, Yogyakarta, Indonesia.

\section{BP Widyobroto}

Department of Animal Production, Faculty of Animal Science, Universitas Gadjah Mada, Yogyakarta, Indonesia.

Received: April 10, 2020 • Accepted: May 28, 2020 • Published Online: June 26, 2020

\begin{abstract}
The background of this study was blood profile and cows' behavior that could be used as a tool to diagnose reproductive status in the dairy cows. This research was aimed to determine biochemical blood profile, progesterone level, and behaviors of Friesian Holstein crossbreed dairy cow in the tropical climates. Fifteen Friesian-Holstein crossbreeds cows, in early lactation, reared by local farmers were divided into two barn types: individual and groups of cows. Blood samples were collected from the jugular vein using a $22 \mathrm{G}$ needle on days 0,14 , and 28. For the determination of blood profile, blood was collected into Vacuntainer $\AA$ blood tubes containing ethylenediaminetetraacetic acid (EDTA) to arrest glycolysis. The blood was transported to the laboratory with a coolbox. The concentration of progesterone in plasma was assayed by enzyme-linked immunosorbent assay (ELISA) using a commercial kit and the biochemical blood profile serum was measured by using microlab 300 . The variables observed were glucose, cholesterol, urea, and non-pregnant progesterone. Data obtained was examined by T-test analysis. The result showed that the Temperature-Humidity Index were 81.3 and 79.6 respectively, there were no significant differences between two observation, in terms of total feeding time $(3.06 \pm 0.48$ and $2.91 \pm 0.22$ hours/day), total water consumption $(86.23 \pm 0.58$ and $85.37 \pm 0.88$ 1/day), total standing (12.70 \pm 0.21 and $12.83 \pm 0.34$ hours/day), total laying (11.30 \pm 0.71 and $11.16 \pm 0.62$ hours/day). The blood profile and progesterone levels were lower than the normal range in dairy cows. Also, the result indicated that blood parameters were not significantly different $(P>0.05)$ between individual pen and group. The result indicated that the progesterone level was not significant in two models of management dairy cows. The conclusion of the research is the climate can affect behavior
\end{abstract}

and the blood parameters. Blood profiles below normal range affect fertility in Friesian-Holstein crossbreed dairy cows.

Keywords: biochemical blood serum, crossbreed FriesianHolstein, tropical climate

\section{Introduction}

The lactation period is a period in which cows produce milk that lasts for 10 months or 305 days. At the start of lactation, bodyweight would decline, since most of the nutrients needed for the formation of milk taken from the cow's body. At that moment, lactating cows having trouble keeping feed substances are needed because her appetite is low. From the time of birth, milk production was increasing rapidly until it reaches peak production in 35-50 days after birth. During the rising phase of lactation in the high yielding cow, milk energy typically exceeds net energy intake such that body reserves were spent for milk synthesis. Despite having a high milk production, loss of excess energy can cause negative effects on metabolism and reproduction (Reynolds 2006).

Dairy cows need nutrients from feed-in high amounts during lactation; especially in early lactation is approximately 3 to 7 times of a cow under physiological conditions dry. If the feed is given insufficient, both in terms of quantity and quality, then the cows will utilize the supply of nutrients in the body by mobilizing the energy stored in body tissues. Although body fat deposits are recognized as the major source of energy reserves, the catabolism of both body fat and protein contribute to nutrient requirements at early lactation (NRC 2001). For efficient production and improving their marketability, the nutritional status of the introduced animals needs to be closely monitored (Chimonyo et al 2002). 
Friesian-Holstein crossbred dairy cows were live in tropical climates such as Indonesia have different behavior than dairy cows that live in subtropical climates, due to the different management that affects productivity and blood profile. Assessment of the nutritional status of cattle using measured blood metabolite concentrations was more accurate than using assessment of body weights or condition scores alone. Serum concentrations of metabolites such as glucose, cholesterol, Non-esterified fatty acids, blood urea nitrogen, creatinine, total proteins, albumin, globulin, and minerals were commonly used to assess the nutritional status of cattle. The use of blood metabolites has been applied mainly in dairy cows (Whitaker et al 1999).

Biochemical blood profiles such as urea, creatinine, total protein, total cholesterol, triglycerides, calcium, and phosphorus were variated during pregnancy, pregnant, postpartum, or during the dry period (Piccione 2012). Furthermore, blood profile which forms the basis of creating reference values for assessing the nutritional status of animals has not yet been established for the Friesian-Holstein crossbred cows in under a tropical condition. The objective of this research was to determine the relationship of blood parameters with reproduction status in early lactation dairy cows also identify the effect of rearing management in those parameters.

\section{Materials and Methods}

\section{Materials}

This research was conducted on local dairy farms in Yogyakarta, Indonesia. The research was carried out during 2 months of lactation. This research used fifteen early lactation Friesian Holstein cows, permanent enclosure barn with cement floor, half animals $(n=7)$ were reared in the individual barn and the others $(n=8)$ were reared in a group barn. The individual barn was a barn in the backyard of farmers' house and group barns were not barn in the backyard of the house. All diets were the same which offered twice morning and afternoon. Drinking water was given ad libitum. Analysis of samples was conducted in the Laboratory of Integrated Research and Testing (LPPT) Universitas Gadjah Mada.

\section{Cows behavior and environmental data}

Observation of the behavior of dairy cows was carried out for $24 \mathrm{~h}$ on the first day and last day of the first month of lactation. Observations were made to determine the behavior of dairy cows. The observed behaviors included feeding duration, drinking time, standing, and lying duration. The material used includes a digital clock to measure the duration of livestock behavior and HTC-2 ${ }^{\odot}$ thermohygrometer is used to measure environmental temperature $\left({ }^{\circ} \mathrm{C}\right)$ and used to measure relative humidity $(\%)$. The Temperature Humidity
Index formula used for these studies was $\mathrm{THI}=\mathrm{Tdb}-[0.55-$ $(0.55 \times \mathrm{RH} / 100)] \times(\mathrm{Tdb}-58)$ where $\mathrm{Tdb}$ : ambient temperature in ${ }^{\circ} \mathrm{F}, \mathrm{RH}$ : relative humidity in $\%$.

\section{Blood preparation and analyses}

Blood samples were collected from the jugular vein using a $22 \mathrm{G}$ needle every 2 weeks for a month. The blood preparation for determinations of glucose, cholesterol, and urea, blood were collected into Vacuntainer ${ }^{\circledR}$ blood tubes containing ethylenediaminetetraacetic acid (EDTA) to arrest glycolysis. The blood was transported to the laboratory with a coolbox. The blood was centrifuged for 15 minutes at 3000 rpm within 2 hours after collection. The plasma was collected and stored at $-15^{\circ} \mathrm{C}$ until further analysis. From the plasma samples, glucose, cholesterol, and urea were measured using spectrophotometer Microlab $^{\circledR} 300$ (Sitaresmi et al 2017). The concentration of progesterone in plasma was determined as a solid-phase competitive enzyme-linked immune sorbent assay (ELISA, DRG, Germany). Each plasma sample was tested in duplicate and the average absorbance reading of each sample was read using a multi-scan spectrophotometer. The concentration of progesterone plasma sample was determined by simple interpolation of the absorbance reading of each sample to standard curve of a standard hormone, the concentration of which has been determined by the manufacturer (Widayati et al, 2018).

\section{Data analysis}

The data of dairy cows behavior and blood parameters were tested using Student T-test in SPSS 20.

\section{Results and Discussion}

\section{Cows behavior and environmental data}

Humidity and environmental temperature are very influential in the physiological condition of the dairy cows. Environmental temperature is very influential in environmental humidity. Yani and Purwanto (2006) state that the process of evaporation from the body of Friesian Holstein (FH) cows will be hampered so that it experiences heat stress at high temperatures and humidity. The results of measurements of temperature and humidity of the barn during the study are presented in Table 1.

The average of THI (Temperature-Humidity Index) in first and last observation 81.3 and 79.6 respectively. Williamson and Payne (1993) reported that Friesian Holstein dairy cows will be comfortable at a THI value below 72. THI value between 72 and 79 the livestock will experience mild stress, THI value between 80 and 89 the livestock will experience moderate stress, and if the THI value between 90 and 97 the livestock will experience severe stress. 
The Temperature-Humidity Index (THI) is a valuable measure that you know when cows are becoming heatstressed. Heat stress is caused by a combination of temperature, relative humidity, solar radiation, air movement, and precipitation. The effect in dairy cows due to heat stress is decreased appetite, increased drinking consumption, decreased metabolism and increased catabolism, increased heat recovery through evaporation, decreased hormone concentration in the blood, increased body temperature, and respiration, and heart rate and changes in behavior. Heat stress can be reduced by lowering the body temperature of cows by spraying water over the entire surface of the body.

Observations on dairy cows for 24 hours are presented in Table 2. The results of the analysis showed that there were no significant differences in all variables. The feeding time is slightly different from the result of Vance et al (2010) which were 236 minutes (3.93 hours) of total feeding time in Friesian-Holstein crossbreed. Genotype had no significant effect on milk fat plus protein yield, while the Friesian Holstein cows were approximately $75 \mathrm{~kg}$ heavier than the Crossbreed cows $(P<0.001)$. When housed indoors, Friesian Holstein cows had a significantly higher dry matter intake than Crossbreed cows.

The total water consumption of dairy cows in observation was higher than the reference. Bond and McDowell (1972) reported that the intake of drinking water for Holstein-Friesian lactation cattle is 57.9 liters per day at an ambient temperature of $18{ }^{\circ} \mathrm{C}$ and 74.7 liters at an ambient temperature of $30{ }^{\circ} \mathrm{C}$. The amount of water supply with sufficient quality can guarantee the continuity of the normal functioning of the livestock body including the reproductive function. Drinking water consumption is related to milk production, if the consumption of drinking water is higher then milk production will be higher because most of the constituent components of milk consist of water.

Standing and lying down is one of the behaviors that were always done by cows, especially dairy cows that are kept by being tied in a cage (housed indoors). Changes in behavior from standing and lying influenced by various things. Lying down is one of the methods carried out by cattle to lower their body temperature. Lying is also a common practice for cattle if they are going to rumination activity. Dairy cows will generally stand up if the animals are fed and when will be milked. Suherman and Purwanto (2015) reported that at high temperatures dairy cows will show standing behavior with a relatively shorter time and lie down with a relatively long time. Yani et al (2007) state that the temperature range in subtropics regions which is good for Friesian Holstein is 5 to $25^{\circ} \mathrm{C}$ so that Friesian-Holstein cattle are very sensitive to changes in microclimate especially temperature and humidity. Different management strategies can improve the reproductive performance of lactating dairy cows under heat stress conditions. Intensive cooling, for instance, can reduce heat stress that results in increased fertility (Collier et al 2006).

Table 1 The temperature and humidity conditions in the first and second observation.

\begin{tabular}{lccc}
\hline Variable & Time & First observation & Second observation \\
\hline Temperature $\left({ }^{\circ} \mathrm{C}\right)$ & 06.00 & 27.7 & 26.4 \\
& 12.00 & 30.9 & 31.3 \\
& 18.00 & 28.1 & 30.5 \\
\cline { 2 - 4 } & 24.00 & 27.2 & 27.8 \\
\cline { 2 - 4 } Humidity (\%) & Average & 28.5 & 29 \\
\cline { 2 - 4 } & 06.00 & 89 & 93 \\
& 12.00 & 82 & 70 \\
Temperature-Humidity Index & 18.00 & 80 & 78 \\
\hline
\end{tabular}

Table 2 The data on dairy cows' behavior for 24 hours.

\begin{tabular}{|c|c|c|}
\hline Variable & First observation & Second observation \\
\hline Total feeding time (hours/day) ${ }^{\mathrm{ns}}$ & $3.06 \pm 0.48$ & $2.91 \pm 0.22$ \\
\hline Water consumption (liters/day) ${ }^{\mathrm{ns}}$ & $86.23 \pm 0.58$ & $85.37 \pm 0,88$ \\
\hline Standing (hours/day) ${ }^{\mathrm{ns}}$ & $12.70 \pm 0.21$ & $12.83 \pm 0.34$ \\
\hline Laying time (hours/day) ${ }^{\text {ns }}$ & $11.30 \pm 0.71$ & $11.16 \pm 0.62$ \\
\hline
\end{tabular}




\section{Biochemical blood profile}

The blood profile concentration observed (Table 3) show that the biochemical blood profile in Friesian-Holstein cows in tropical climate have lower concentration rather than the normal range from the previous references also there was no significant difference in the serum level of glucose, cholesterol, and blood urea nitrogen between individual and group pens $(P>0.05)$.

Blood profiles used in dairy cows to help identify problems of nutrition and management. The relationship between reproduction cows with nutritional status is closely related (Wettemann et al 2003). Nutritional deficiencies have been reported as major factors hindering cattle production systems in tropical regions. Nutritional deficiencies could directly influence the reproductive efficiency, such as low reproductive performance and productivity (Salem et al 2006). For instance, alteration in post-absorptive metabolism of heatstressed cows fails to enlist glucose "sparing" mechanisms (Baumgard et al 2011). Furthermore, because of the reduction of feed intake and the rise of maintenance requirements, heatstressed cows may decrease the nutrient availability for milk production (Wang et al 2010).

The values found for blood metabolites were within the reference values for the species and category (Bezerra et al 2013). Glucose is one of the most important metabolic substrates required for the function of the reproductive process in cows. Previous studies reported that low levels of glucose can cause high levels of non-esterified fatty acids (NEFA) which have toxic effects on the follicle, the oocyte, embryo, and fetus and decrease the secretion of GnRH from the hypothalamus (Adewuyi et al 2005). Decreased GnRH levels inhibit the synthesis of FSH and LH in the anterior pituitary and caused follicle does not grow and does not trigger estrus. (Oguike 2008). Ruminants, in general, required glucose for growth of the body, such as the fetus and placenta tissue growth, udder, and milk production (Kohn et al 2005).

The normal blood glucose levels in dairy cows were $68.40 \mathrm{mg} / \mathrm{dl}$ in normal cycles and $48.58 \mathrm{mg} / \mathrm{dl}$ in repeat breeding cows (Eryavus et al, 2008). In this study, glucose levels were not significantly different in each management of rearing also the results showed the glucose level in this study was lower than the normal range this could make incline the potential of reducing reproductive status in those cows (Damptey et al 2014). For instance, alteration in postabsorptive metabolism of heat-stressed cows fails to enlist glucose "sparing" mechanisms (Baumgard et al 2011). Furthermore, because of the reduction of feed intake and the rise of maintenance requirements, heat-stressed cows may decrease the nutrient availability for milk production (Wang et al 2010). The higher results reported by Eryavus et al. (2008) was $92.36 \mathrm{mg} / \mathrm{dl}$ in the second month of lactation dairy cows. This indicates that glucose is not the cause of postpartum anestrus (Khan et al 2009).

In the present study, the total serum cholesterol concentrations higher in the group type than the individual $(P$ $<0.05)$. Cholesterol is a fatty substance that circulates in the blood and is produced by the liver (Murray et al, 2003). The single pen or housing in animals reported decreased fat mass ratio in animals (Nagy et al 2002). The previous study suggests that behavioral or social interactions exert an important effect on body fat mass composition, those could be caused by the higher corticosterone concentration in the animal which reared in a single pen and disturbs the cholesterol and body fat mass production (Skalicky et al 2001). Cows that lack fat in the body rations could suppress oestrus and ovulation, or reducing the number of ovum. The lack of fat in cows can be followed by a silent heat or short estrus (subestrus), extend the period of anestrus, or repetitive mating (Hardjopranjoto, 1995).

The present study indicated blood urea nitrogen (BUN) level in normal range also there no significantly different in BUN profile I those two group cows. The results of the analysis of cow blood urea nitrogen appear lower in cows experiencing postpartum anestrus (Świątkiewicz et al 2010), which similar results were reported by Ahmad et al. (2004) that the average levels of urea $30.88 \mathrm{mg} / \mathrm{dl}$ in normal estrus cows and $33.80 \mathrm{mg} / \mathrm{dl}$ in postpartum anestrus cows. However, it has not obtained a clear boundary of blood urea nitrogen that can lead to the emergence of post-partum estrus in cows (Hess et al, 2005). Blood plasma urea is one of the indicators used to assess the metabolism of nitrogen in the rumen (Kohn et al 2005).

\section{Non-pregnant progesterone levels}

The serum progesterone level from individual pen and group did not differ (Table $3 ; P>0.05$ ). According to Astuti (2000) reported that a cow showed the highest levels of progesterone on the $16^{\text {th }}$ day after estrus. The result showed that the progesterone plasma was $3.06 \pm 4.39 \mathrm{ng} / \mathrm{ml}$. Vandeplassche (1982) found that reproductive hormone progesterone was closely related to gestation. The content in progesterone levels in the blood plasma is greater than $3 \mathrm{ng} / \mathrm{ml}$ indicates that cattle in a state of pregnancy, or greater than 6 $\mathrm{ng} / \mathrm{ml}$ progesterone levels were found in milk on the 24th day of gestation. The content of progesterone levels less than 1 $\mathrm{ng} / \mathrm{ml}$ in the blood plasma or less than $2 \mathrm{ng} / \mathrm{ml}$ in milk, indicated it would not be found corpus luteum or had regressed in the ovary or do not show clinical signs of pregnancy. 
Table 3 Blood parameters and progesterone level of Friesian-Holstein cows on the local farmer.

\begin{tabular}{|c|c|c|}
\hline \multirow{2}{*}{ Parameters } & \multicolumn{2}{|c|}{ Type of Barn } \\
\hline & Individual & Group \\
\hline Glucose $\left(\mathrm{mg} \mathrm{dL}^{-1}\right)$ & $55.43 \pm 11.60$ & $42.22 \pm 9.79$ \\
\hline Cholesterol (mg dL $\left.\mathrm{m}^{-1}\right)$ & $127.41 \pm 48.94$ & $166.90 \pm 57.21$ \\
\hline BUN (mg dL $\left.{ }^{-1}\right)$ & $26.02 \pm 8.10$ & $24.31 \pm 6.83$ \\
\hline Progesterone ng $\mathrm{mL}^{-1}$ & $3.06 \pm 4.39$ & $1.47 \pm 3.21$ \\
\hline
\end{tabular}

\section{Conclusions}

The challenges in tropical areas presented are complex factors such as heat stress and the different physiology of animals. The tropical climate can affect behavior such as total feeding time, water consumption, total laying, and total standing. Blood tests can be used as a tool for assessing the health status of livestock and the nutritional status of individuals. The Friesian-Holstein crossbreed dairy cows in Yogyakarta have lower parameters in glucose and blood urea nitrogen that can affect milk production and reproduction.

\section{Acknowledgments}

The author would thanks the Ministry of Research and Technology which has provided funding research is conducted through the PMDSU Research Fund with grant number 319/SP2H/LT/DRPM/IX/2016.

\section{Conflict of Interest}

The authors declare no conflict of interest.

\section{References}

Adewuyi AA, E Gurys, and van Eerdenburg FJCM (2005) Non esterified fatty acids (NEFA) in dairy cattle. A review. Veterinary Quarterly 27:117-126.

Ahmad I, Lodhi LA, Qureshi ZI, Younis M (2004) Studies on blood glucose, total protein, urea and cholesterol levels in cyclic, non-cyclic and endometritic crossbred cows. Pakistan Veterinary Journal 24:9294.

Astuti P (2000) Comparison Of Progesterone Contained In Various Samples (Blood, Milk, Urine) Using Radioimmunoassay Techniques. Bulletin Petemakan 24:51-56.

Baumgard LH, Wheelock JB, Sanders SR, et al. 2011. Postabsorptive carbo-hydrate adaptations to heat stress and monensin supplementation in lactating Holstein cows. Journal of Dairy Science 94:5620-33.

Bezerra LR, Gonzaga Neto S, Medeiros AN, Mariz TM de A, Oliveira RL, Cândido, EP and Silva AMA (2013) Feed restriction followed by re-alimentation in prepubescent Zebu females. Tropical Animal Health and Production 45:1161-1169.
Bond J, McDowell RE (1972) Repoductive performance and physiological responses of beef females as affected by a prolonged high environmental temperature. Journal of Animal Science 35:820829.

Chimonyo M, Hamudikuwana H, Kusina NT, Ncube I (2002) Changes in stress-related plasma metabolite concentrations in working Mashona cows on dietary supplementation. Livestock Production Science 73:165-173.

Collier, RJ, Dahl GE, VanBaale, MJ (2006) Major advances associated with environmental effects on dairy cattle. Journal of Dairy Science 89:1244-1253.

Damptey JK, Obese FY, Aboagye GS, Ayim-Akonor M, Ayizanga RA (2014) Blood metabolite concentrations and postpartum resumption of ovarian cyclicity in sanga cows. South African Journal of Animal Science 44:10-17.

Hardjopranjoto HS (1995) Ilmu Kemajiran pada Ternak (Science of Infertility on Livestock). Airlangga University Press, Surabaya.

Hess BW, Lake SL, Scholljegerdes EJ, Weston TR, Nayigihugu V, Molle JDC, Moss GE (2005) Nutritional controls of beef cow reproduction. Journal of Animal Science 83:90-106.

Khan HM, TK Mohanty, M Bhakat, VS Raina and AK Gupta (2009) Effect of season on reproductive performance of buffaloes at an organized farm. Indian Journal of Animal Reproduction 30:6-9

Kohn RA, Dinneen MM, Russek-Cohen E (2005) Using blood urea nitrogen to predict nitrogen excretion and efficiency of nitrogen utilization in cattle, sheep, goats, horses, pigs, and rats. Journal of Animal Science 83:879-889

Murray RK, DK Granner, PA Mayes, and VW Rodwell (2003) Harper Biochemistry. $25^{\text {th }}$ Edition. EGC Publisher, Jakarta.

Nagy TR, Krzywanski D, Li J, Meleth S, and Desmond R (2002) effect of group vs. Single housing on Phenotypic Variance in C57BL/6J Mice. Obesity Research 10:412-415.

National Research Council (2001) Nutrients requirements of dairy cattle. 7th Ed.,Washington, D.C.: National Academy Press, 408.

Oguike MO, Okocha NL (2008) Reproductive performance of rabbits remated at different intervals post- partum. African Journal of Agricultural Research 3:412-415.

Piccione G, Messina V, Marafioti S, Casella S, Giannetto C, Fazio F (2012) Changes of some haematochemical parameters in dairy cows during late gestation, post partum, lactation and dry periods. Veterinarija ir zootechnika 58:59-64. 
Reynolds CK (2006) Production and metabolic effects of site of starch digestion in lactating dairy cattle. Animal Feed Science and Technology 130:78-94.

Salem, MB, M Djemali, C Kayouli and A Majdoub (2006) A review of environmental and management factors affecting the reproductive performance of Holstein-Friesian dairy herds in Tunisia. Livestock Research for Rural development 18:4.

Sitaresmi PI, Widyobroto BP, Bintara S, and Widayati DT (2017) Progesterone and biochemical profile of Ettawa-Saanen Crossbreed Goats in Turi Area, Yogyakarta-Indonesia. International Journal of Dairy Science 12:289-294.

Skalicky M, Narath E, and Viidik A (2001) Housing conditions influence the survival and body composition of ageing rats. Experimental Gerontology 36:159-170.

Suherman, D. dan B. P. Purwanto (2015) Respon fisiologis sapi perah dara fries holland yang diberi konsenstrat dengan tingkat yang berbeda. Jurnal Sain Peternakan Indonesia 10:13-21.

Świątkiewicz J, Koreleski A, Arczewska (2010) Laying performance and eggshell quality in laying hens fed diets supplemented with prebiotics and organic acids. Czech Journal of Animal Science 7:294-306.

Vance ER, Ferris CP, Elliott CT, Kilpatrick DJ (2010) Food intake and feeding behaviour of Holstein-Friesian and Jersey x HolsteinFriesian crossbreed dairy cows. Proceedings of the British Society of Animal Science and the Agricultural Research Forum. Cambridge University Press. United Kingdom. 1:141.

Vandeplassche M (1982) Reproductive Efficiency in Cattle: A Guidelinefor Project in Developing Countries. FAO. Rome.
Wang JP, Bu DP, Wang JQ (2010) Effect of saturated fatty acid supple-mentation on production and metabolism indices in heatstressed mid-lactation dairy cows. Journal of Dairy Science 93:41217.

Wettemann R, Lents C, Ciccioli N, White F, Rubio I (2003) Nutritional and suckling mediated anovulation in beef cows. Journal of Animal Science 81:48-59.

Whitaker DA, Goodger WJ, Garcia M, Perera BMAO, Wittwer F (1999) Use of metabolic profiles in dairy cattle in tropical and subtropical countries on smallholder dairy farms. Preventive Veterinary Medicine 38:119-131

Widayati DT, Sitaresmi PI, Bintara S, Widyobroto BP (2018) Estrus detection through vaginal $\mathrm{pH}$ in Saanen Ettawah Crossbreed goats. Pakistan Journal of Biological Sciences 21:383-386.

Williamson G, Payne WJA (1993) Pengantar Peternakan di Daerah Tropis. Diterjemahkan oleh: S.G.N. Djiwa Darmaja dan Ida Bagus Jagra. Gadjah Mada University Press, Yogyakarta.

Yani A, Purwanto BP (2006) Pengaruh Iklim Mikro Terhadap Respon Fisiologis Sapi Peranakan Frisian Holstein dan Modifikasi Lingkungan Untuk Meningkatkan Produktivitasnya. Media PeternakanBogor 29:35-46.

Yani A, Suhardiyanto H, Hasbullah R, dan Purwanto BP (2007) Analisis dan Simulasi Distribusi Suhu Udara Pada Kandang Sapi Perah Menggunakan Computational Fluid Dynamics (CFD). Media Peternakan. Bogor 30:218-228. 